\title{
Effect of farming practices on growth and mortality rates in triploid and diploid eastern oysters Crassostrea virginica
}

\author{
Sarah Bodenstein ${ }^{1, *}$, William C. Walton ${ }^{2}$, Todd D. Steury ${ }^{3}$ \\ ${ }^{1}$ Louisiana State University Agricultural Center, 2288 Gourrier Ave, 70820 Baton Rouge, LA, USA \\ ${ }^{2}$ Auburn University, School of Fisheries, Aquaculture, and Aquatic Science, 36528 Dauphin Island, AL, USA \\ ${ }^{3}$ Auburn University, School of Forestry and Wildlife Sciences, 36849 Auburn, AL, USA
}

\begin{abstract}
Commercial off-bottom aquaculture of the eastern oyster Crassostrea virginica is challenged by repeated summer mortality events that appear to affect triploid oysters disproportionally. Many farmers believe common farming practices, especially when performed during hot summer months, may increase triploid mortality. The goal of this study was to investigate how diploid and triploid oysters react to common stressors imposed by farmers: tumbling during size grading and desiccation to prevent biofouling. Triploid and diploid oysters were deployed in floating cages at $3 \mathrm{farm}$ sites along the US Gulf of Mexico coast. In May and July, oysters in 7 cages were subjected to 1 of 6 stress treatments: 1 of 3 levels of desiccation $(18,24$, or $48 \mathrm{~h})$ mixed with 1 of 2 levels of tumbling (tumbled or not tumbled), along with a never handled, submersed control. The mortality and growth rate of oysters were assessed in June, August, and September. Growth rates of both ploidies were affected by compounding stressors; that is, treatments with both tumbling and the longest desiccation period exhibited slower growth. Triploid oysters exhibited a greater increase in mortality in response to farm stress than diploid oysters, and mortality increased in all oysters subjected to extreme stress treatments when compared to the control. Based on this study, farmers should limit the desiccation time of oysters (particularly triploids) in the summer months to avoid any mortality or reduced growth resulting from compounding stressor effects.
\end{abstract}

KEY WORDS: Oysters $\cdot$ Triploids $\cdot$ Mortality $\cdot$ Stress $\cdot$ Aquaculture $\cdot$ Desiccation $\cdot$ Tumbling

\section{INTRODUCTION}

Eastern oysters Crassostrea virginica are grown commercially in aquaculture operations throughout the east coast of North America and the Gulf of Mexico. The estimated value of aquaculture production for the US eastern oyster in 2015 was \$173 million (NOAA Fisheries 2016). The industry is growing quickly, especially in the northern Gulf of Mexico along the coasts of Alabama, Mississippi, Florida, and Louisiana (Casas et al. 2017). In Alabama alone in 2016, oyster farmers harvested at least 2.6 million oysters with a farm-gate value of nearly $\$ 2$ million

${ }^{*}$ Corresponding author: sboden2@lsu.edu
(Grice \& Walton 2017). However, a major problem limiting industry success is frequent summer mortality events (Casas et al. 2017, Wadsworth et al. 2019).

Summer mortality is a concern for both diploid and triploid oysters, both of which are commonly used in aquaculture. Triploidy is a condition in which the animal contains 3 sets of chromosomes (3n), rather than the usual 2 sets ( $2 \mathrm{n}$ or diploidy). Triploid oysters have reduced gametogenesis and therefore rarely spawn. Consequently, they expend less energy on reproduction and may grow faster and reach market size $(75 \mathrm{~mm})$ sooner than diploid oysters. For example, one study indicated that whole wet weight of

() The authors 2021. Open Access under Creative Commons by Attribution Licence. Use, distribution and reproduction are unrestricted. Authors and original publication must be credited. 
triploids can be up to $70 \%$ more than diploids grown for the same amount of time under the same conditions (Ibarra et al. 2017). Reduced gonad production in triploids may also improve the meat quality (Housin et al. 2019). Thus, the use of triploid eastern oysters by commercial aquaculture has become increasingly popular in recent years. In 2014, triploids made up $91 \%$ of growers' plantings in Virginia (Hudson \& Murray 2015). Similarly, the Auburn University Shellfish Laboratory (AUSL) produced and shipped 36 million triploid seed to off-bottom oyster farms in the Gulf of Mexico region in 2017, far outpacing diploid orders (F. S. Rikard unpubl. data).

Despite the benefits of triploid oysters for commercial aquaculture, farmers in the industry are increasingly concerned that triploid oysters are more sensitive to summer mortality events. Farmers in South Australia find triploid Pacific oysters C. gigas to be 'fragile' and are more careful when handling them during the summer months (S. Allen pers. comm.). In summer 2016, several farmers in Alabama noticed unexpectedly high levels of triploid oyster mortality in 1 to 2 yr old oysters at farm sites; mortality rates ranging from 19 to $100 \%$ were observed, with the majority of the mortality occurring over only a few weeks in early July (Wadsworth 2017). In early May 2018, a local commercial farm located in Grand Bay, Alabama reported triploid mortality of around 30\% with no noticeable increase in diploid mortality (W. C. Walton pers. obs.). The cause of these mortality events remains inconclusive, but the need to reduce triploid (and diploid) summer mortality is vital to the continued success of this oyster industry.

Oysters are subject to a number of naturally occurring environmental stressors, as well as stressors imposed by aquaculture activities, that may increase risk of mortality. Furthermore, these farm and environmental stressors may contribute to differences in mortality rates between triploid and diploid oysters (Wadsworth et al. 2019). For example, low salinity (an environmental stressor) can cause triploid oysters to grow more slowly than diploid oysters (Callam et al. 2016). Such a stressor could also contribute to higher mortality rates. Desiccation and tumbling are 2 potential stressors imposed by aquaculture farms that may influence oyster mortality rates. Desiccation is the practice of exposing oysters to ambient air for extended periods of time to reduce biofouling and infestation by many marine parasites (Grodeska et al. 2017). A common farming practice in the US Gulf Coast region is to desiccate oysters for 18 to $24 \mathrm{~h}$ duration once a week. Tumbling is the process of running oysters through a rotary style mechanical grader, or tumbler, in order to sort the oysters by size (Ring 2012). Tumbling has the added benefit of chipping away fragile new shell growth, thus improving the shell shape of the oysters for market. It is common for farmers to tumble their oysters once per month (Ring 2012). Ultimately, the interaction of multiple stressors, both environmental and farm-based, must be observed to understand their effects on the growth and mortality of both diploid and triploid oysters.

In this experiment, we sought to test 2 possible causes of increased summer mortality by subjecting both diploid and triploid oysters to common stressors potentially imposed by farmers: tumbling and desiccation. We predicted that triploid oysters would exhibit higher mortality rates in response to these farmbased stressor events. Growth and mortality rates of diploid and triploid oysters subjected to different levels of these stressors were compared across 3 farm sites. Based on the results, we sought to recommend best farm management practices to reduce summer mortality.

\section{MATERIALS AND METHODS}

\subsection{Experimental set up and sampling}

This experiment was conducted at 3 farm sites across the northern Gulf of Mexico (Fig. 1). Sites in different US states were chosen so that results would reflect the variable growing conditions across the US northern Gulf of Mexico. The first site was at Grand

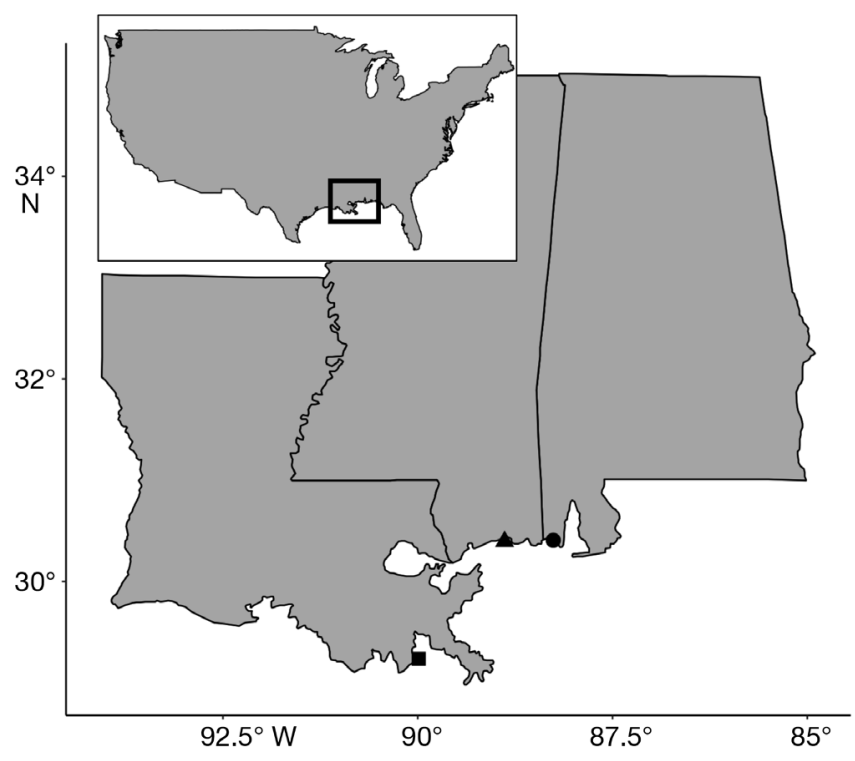

Fig. 1. The 3 farm sites used in this study: Grand Bay, AL (๑), Deer Island, MS ( $\mathbf{\Delta})$, and Grand Isle, LA (ם), USA 


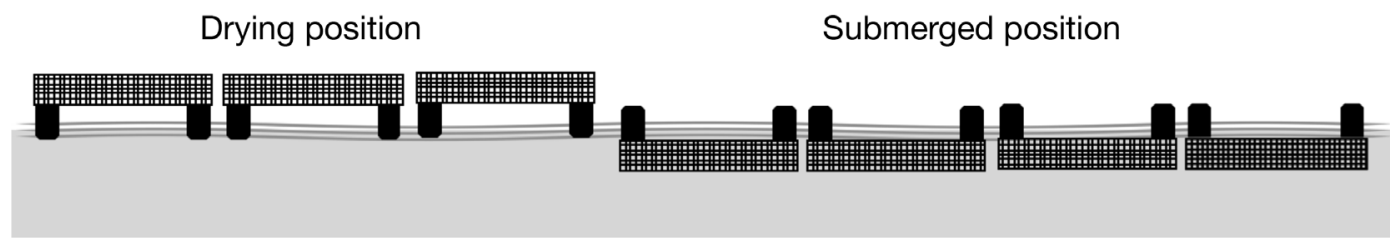

Fig. 2. The OysterGro set-up for a farm site. Three cages are in the drying position and 4 are in the submerged position. Image credit: Victoria Pruente, Auburn University Shellfish Laboratory, AL, USA

Bay Oyster Park in Grand Bay, Alabama, at an AUSL research site. The second site was at Deer Island in Biloxi, Mississippi, in cooperation with the Mississippi Department of Marine Resources. The third site was at the Michael Voisin Oyster Research Lab and Hatchery in Grand Isle, Louisiana, in cooperation with Louisiana Sea Grant and Louisiana State University.

At each of the 3 sites, 7 OysterGro ${ }^{\circledR}$ cages were deployed in early April 2018 (Fig. 2). Each cage held six $12 \mathrm{~mm}$ mesh grow-out bags $(36 \times 18.9 \times 7.6 \mathrm{~cm})$. Three bags in each cage contained diploid oysters and 3 bags contained triploid oysters (produced from crossing diploids and tetraploids), in an alternating pattern. Thus, 42 bags were deployed at each site, with a grand total of 126 bags across all 3 sites. All oysters were 12 mo old, half-sibling triploids and diploids spawned and raised at AUSL and grown out in Portersville Bay in 2017. Each bag was initially stocked with 75 oysters, well below the standard stocking density of 150 , to ensure overcrowding did not contribute to stress or mortality. All oysters were allowed to acclimate for 1 mo after being deployed. In early May, the first stressor trial was imposed on oysters at all 3 sites because it was qualitatively observed in prior years that oyster mortality begins to rise at that time of year, putatively in response to warming water temperatures. Additionally, a commercial farmer near the Alabama study site was reporting high mortalities at that time (W. C. Walton pers. obs.).

At each site, each of 6 cages was randomly assigned to a stressor treatment based on 3 levels of desiccation $(18,24$, or $48 \mathrm{~h})$ mixed with 2 levels of tumbling (tumbled through a mechanical grader/not tumbled), while 1 cage served as a never handled, submersed control (Table 1). Two HOBO Pendant ${ }^{\circledR}$ MX Water Temperature data loggers were placed at each site to track temperature fluctuations. To ensure the rate of temperature change would more accurately reflect conditions inside an oyster shell, each logger was inserted between 2 oyster shells bound together with zip ties. One logger was placed inside a control bag (never desiccated, never tumbled) to monitor water temperature for the duration of the experiment. The other logger was placed inside a bag in the $48 / \mathrm{T}$ treatment to monitor temperature changes when oysters were taken out of the water to be tumbled and desiccated. At the Grand Isle and Deer Island sites, salinity data were collected from USGS sensors (United States Geological Survey 2018) and at Grand Bay, salinity data were collected from an Aqua TROLL sonde at the site.

Oysters that were desiccated and not tumbled stayed in their OysterGro cage, which was flipped to the drying position, with floats down. The cage was then flipped back over to the submerged position, floats up, once the appropriate amount of time had passed. Bags of oysters that were desiccated and tumbled were removed from their cage and taken to the mechanical grader at each site to be tumbled ( $\leq 20$ min transport). Oysters from each bag were fed through the grader, one bag at a time in a random order, and all oysters were placed back in the bag before the next one was started. Tumbled oysters were left to desiccate on land overnight before being returned to their respective cages, already flipped to the drying position, the following morning. These cages were then flipped back over once the appropriate amount of desiccation time had passed, inclusive of the overnight desiccation on land.

Oysters at each site were allowed to recover in situ for approximately 1 mo after the stressor trial at that site had been completed. In June, samples were taken to assess oyster mortality and growth rate. Due

Table 1. List of the control treatment and the 6 stressor treatments that oysters were subjected to in the experiment

\begin{tabular}{|ll|}
\hline Stressor treatment & Abbreviation \\
\hline 0 h desiccation and no tumbling & $0 / \mathrm{NT}$ \\
$18 \mathrm{~h}$ desiccation and no tumbling & $18 / \mathrm{NT}$ \\
$18 \mathrm{~h}$ desiccation and tumbling & $18 / \mathrm{T}$ \\
$24 \mathrm{~h}$ desiccation and no tumbling & $24 / \mathrm{NT}$ \\
$24 \mathrm{~h}$ desiccation and tumbling & $24 / \mathrm{T}$ \\
$48 \mathrm{~h}$ desiccation and no tumbling & $48 / \mathrm{NT}$ \\
48 h desiccation and tumbling & $48 / \mathrm{T}$ \\
\hline
\end{tabular}


to very low overall mortality observed at the June timepoint, stressor trials were repeated in July to impose the stressors during a warmer period. Approximately 1 mo after the second round of stressor trials, in August, mortality and growth rates were again assessed. In September, one final round of sampling was performed to track any residual impacts that imposed stress had on mortality and growth. Analysis was performed on the sum of the mortality measurements collected in June, July, and August.

Mortality was measured by counting the number of dead oysters in each bag at the end of the study period and percent mortality for each bag was calculated by dividing this by 75 (initial planting density). Length of 5 haphazardly selected oysters from each bag were measured using calipers (nearest $0.01 \mathrm{~mm}$ ). Length was measured from umbo to the tip of the bill. Average growth rates were calculated, in $\mathrm{mm} \mathrm{d}^{-1}$, using the change in length $(\mathrm{mm})$ from the average initial size of the oysters in April to the final individual size in September 2018 (to account for initial differences in average size between ploidy treatments).

\subsection{Data analysis}

All analyses were completed using R v.1.0.153 ( $\mathrm{R}$ Core Team 2018). The growth rate data were normally distributed but percent mortality data were not. Therefore, the percent mortality data were $\log$ transformed to restore normality. Linear mixed-effects models (lme4 package, Bates et al. 2015) were used to examine the 3 fixed factors (ploidy, treatment, and their interaction) across site and cage (blocked random factors) for the response variables (growth rate and mortality, Eqs. 1 \& 2, respectively). Eqs. (1) \& (2) were compared to corresponding linear mixed-effects models that did not contain an interaction term using an ANOVA for linear model fit. The more complicated model (containing the interaction term) was considered a significant improvement over the simpler model if $\mathrm{p}<0.05$ and the Akaike's information criterion (AIC) value was lower. If the interaction term was significant, then we analyzed diploid and triploid data separately to further elucidate the results.

$$
\begin{aligned}
\text { Growth }= & \left.\mu+\beta_{1}(\text { ploidy })+\beta_{2} \text { (treatment }\right)+ \\
& \beta_{3}(\text { ploidy } \times \text { treatment })+ \\
& \varepsilon_{\text {Site/Cage }} \sim N\left(0, \sigma_{\text {Site/Cage }}\right)+ \\
& \varepsilon_{\text {random }} \sim N\left(0, \sigma_{\text {random }}\right)
\end{aligned}
$$

where growth is the dependent variable of growth rate in $\mathrm{mm} \mathrm{d}^{-1}, \mu$ is the overall mean, ploidy is the ef- fect of ploidy (triploid or diploid), treatment is the effect of the stress treatment $(0 / \mathrm{NT}, 18 \mathrm{NT}, 18 / \mathrm{T}, 24 \mathrm{NT}$, $24 / \mathrm{T}, 48 / \mathrm{NT}, 48 / \mathrm{T}), \varepsilon_{\text {Site/Cage }}$ is the random effect of cage nested within site, $\varepsilon_{\text {random }}$ is the random effect, and $\beta$, $N$, and $\sigma$ are error terms.

$$
\begin{aligned}
\text { Mortality }= & \mu+\beta_{1}(\text { ploidy })+\beta_{2}(\text { treatment })+ \\
& \beta_{3}(\text { ploidy } \times \text { treatment })+ \\
& \varepsilon_{\text {Site/Cage }} \sim N\left(0, \sigma_{\text {Site/Cage }}\right)+ \\
& \varepsilon_{\text {random }} \sim N\left(0, \sigma_{\text {random }}\right)
\end{aligned}
$$

where mortality is percent mortality and all other terms are as described for Eq. (1) above. Additionally, a linear model was used to analyze the relationships of temperature, salinity, and ploidy (fixed, independent variables) to the dependent variable of mortality over the duration of the study (Eq. 3). This linear model was compared to a corresponding linear model that did not contain interaction terms using ANOVA for linear model fit. The more complicated model (containing interaction terms) was considered a significant improvement over the simpler model if $\mathrm{p}<0.05$.

$$
\begin{aligned}
\text { Mortality }= & \left.\mu+\beta_{1} \text { (temperature }\right)+ \\
& \left.\left.\beta_{2} \text { (salinity }\right)+\beta_{3} \text { (ploidy }\right)+ \\
& \varepsilon_{\text {random }} \sim N\left(0, \sigma_{\text {random }}\right)
\end{aligned}
$$

where temperature is the effect of water temperature and salinity is the effect of salinity.

\section{RESULTS}

\subsection{Growth rates}

There was no significant interaction between ploidy and treatment in our analysis of oyster growth rates (ANOVA for linear model fit; $\mathrm{p}=0.45, \mathrm{AIC}=-482.0$ as compared to AIC $=-488.3$ of simpler model) and thus the interaction term was removed. At the conclusion of the field study, the factors that significantly affected growth rate were ploidy and the stress treatments 24/T and 48/T (Table 2). Triploid oysters grew $0.06 \mathrm{~mm} \mathrm{~d}^{-1}(\mathrm{CI}=0.01)$ faster than diploid oysters across all stress treatments $(\mathrm{p}<0.01)$. Triploids had an average growth rate of $0.23 \mathrm{~mm} \mathrm{~d}^{-1}(\mathrm{CI}= \pm 0.01)$ compared to the average diploid growth rate of $0.16 \mathrm{~mm} \mathrm{~d}^{-1}$ $(\mathrm{CI}= \pm 0.03)$. The 2 stress treatments that affected growth caused oysters to grow more slowly than in other treatments (Table 2). Oysters (diploid and triploid) in the 24/T stress treatment grew $0.03 \mathrm{~mm} \mathrm{~d}^{-1}$ $(\mathrm{CI}=0.03)$ slower than oysters in the control treatment ( $p=0.03$ ), and oysters in the $48 / \mathrm{T}$ stress grew $0.040 \mathrm{~mm}$ $\mathrm{d}^{-1}(\mathrm{CI}=0.03)$ slower than oysters in the control treat- 
ment $(\mathrm{p}<0.01)$. The growth rates of oysters in treatments $24 / \mathrm{T}$ and $48 / \mathrm{T}$ were not significantly different from each other or the remaining treatments (18/NT, 18/T, 24/NT, and 48/NT; all p > 0.06) (Fig. 3).

Table 2. Linear mixed-effects models for growth rate and mortality with 2 ploidies (triploid and diploid) under 6 stress treatments $(18 / \mathrm{NT}, 18 / \mathrm{T}, 24 / \mathrm{NT}, 24 / \mathrm{T}, 48 / \mathrm{NT}, 48 / \mathrm{T})$ and the control. Significant p-values are given in bold. See Table 1 for treatment abbreviations

\begin{tabular}{|c|c|c|c|c|c|}
\hline & df & Estimate & $\mathrm{SE}$ & $t$ & $\mathrm{p}$ \\
\hline \multicolumn{6}{|l|}{ Growth (mm d $\left.{ }^{-1}\right)$} \\
\hline Intercept & 104 & 0.16 & 0.01 & 11.64 & $\leq \mathbf{0 . 0 1}$ \\
\hline Ploidy & 104 & 0.06 & 0.01 & 11.57 & $\leq \mathbf{0 . 0 1}$ \\
\hline Treatment 18/NT & 12 & -0.03 & 0.01 & -2.08 & 0.06 \\
\hline Treatment 24/NT & 12 & -0.02 & 0.01 & -1.95 & 0.08 \\
\hline Treatment 48/NT & 12 & -0.03 & 0.01 & -2.04 & 0.06 \\
\hline Treatment 18/T & 12 & -0.02 & 0.01 & -1.74 & 0.11 \\
\hline Treatment 24/T & 12 & -0.03 & 0.01 & -2.44 & 0.03 \\
\hline Treatment 48/T & 12 & -0.04 & 0.01 & -3.11 & 0.01 \\
\hline \multicolumn{6}{|l|}{ Diploid mortality (\%) } \\
\hline Intercept & 41 & 0.01 & 0.05 & 0.24 & 0.81 \\
\hline Treatment 18/NT & 12 & 0.02 & 0.08 & 0.21 & 0.84 \\
\hline Treatment 24/NT & 12 & 0.03 & 0.08 & 0.37 & 0.72 \\
\hline Treatment 48/NT & 12 & 0.15 & 0.08 & 1.94 & 0.08 \\
\hline Treatment 18/T & 12 & 0.04 & 0.08 & 0.49 & 0.63 \\
\hline Treatment 24/T & 12 & 0.10 & 0.08 & 1.29 & 0.22 \\
\hline Treatment 48/T & 12 & 0.27 & 0.08 & 3.57 & $\leq 0.01$ \\
\hline \multicolumn{6}{|l|}{ Triploid mortality (\%) } \\
\hline Intercept & 41 & 0.05 & 0.07 & 0.71 & 0.48 \\
\hline Treatment 18/NT & 12 & $<0.01$ & 0.10 & -0.01 & 0.10 \\
\hline Treatment 24/NT & 12 & 0.03 & 0.10 & 0.33 & 0.75 \\
\hline Treatment 48/NT & 12 & 0.23 & 0.10 & 2.40 & 0.03 \\
\hline Treatment 18/T & 12 & 0.07 & 0.10 & 0.74 & 0.47 \\
\hline Treatment 24/T & 12 & 0.08 & 0.10 & 0.83 & 0.42 \\
\hline Treatment 48/T & 12 & 0.36 & 0.10 & 3.77 & $\leq 0.01$ \\
\hline
\end{tabular}

\subsection{Mortality}

Triploid oysters had a higher mortality rate than diploid oysters (type II sum-of-squares analysis $\mathrm{p}<$ 0.01). Specifically, on average, triploids had $6.79 \%$ (lower confidence limit [LCL] $=4.13 \%$, upper confidence limit [UCL] $=9.43 \%$ ) higher mortality than diploid oysters (back transformed from the model). Furthermore, stress treatment and ploidy had a significant interaction on oyster mortality (ANOVA for linear model fit; $\mathrm{p}=0.04$, AIC $=-240.4$ as compared to $\mathrm{AIC}=-239.4$ of simpler model). Due to this interaction, the effect of treatment on mortality was analyzed separately for each ploidy using 2 models (Table 2). Diploid oysters in treatment 48/T had significantly higher mortality than diploids in the control treatment ( $\mathrm{p}<0.01$ ), while triploid oysters in both $48 \mathrm{~h}$ desiccation treatments (48/NT and 48/T) had higher mortality than control triploids $(\mathrm{p}<0.01$ for all comparisons; Table 2, Fig. 4). Control diploid oysters experienced $1.32 \%(\mathrm{LCL}=-9.19 \%$, UCL $=13.05 \%)$ mortality, while diploid oysters in treatment 48/T experienced $33.06 \%(\mathrm{LCL}=11.22 \%, \mathrm{UCL}=55.06 \%)$ mortality at the conclusion of the field study. In contrast, control triploid oysters experienced 5.38\% (LCL $=-9.20 \%$, $\mathrm{UCL}=22.32 \%$ ) mortality, and triploid oysters in treatments 48/NT and 48/T experienced 33.06\% (LCL = $20.97 \%$, UCL $=55.13 \%)$ and $51.62 \%(\mathrm{LCL}=16.59 \%$, $\mathrm{UCL}=77.54 \%$ ) mortality, respectively (Table 2, Fig. 4). Triploid and diploid oysters in other treatments had levels of mortality that fell between those seen in the control and in treatments 48/NT and 48/T, although none of the mortality rates were significantly different from other treatments (all $\mathrm{p}>0.42$ ).

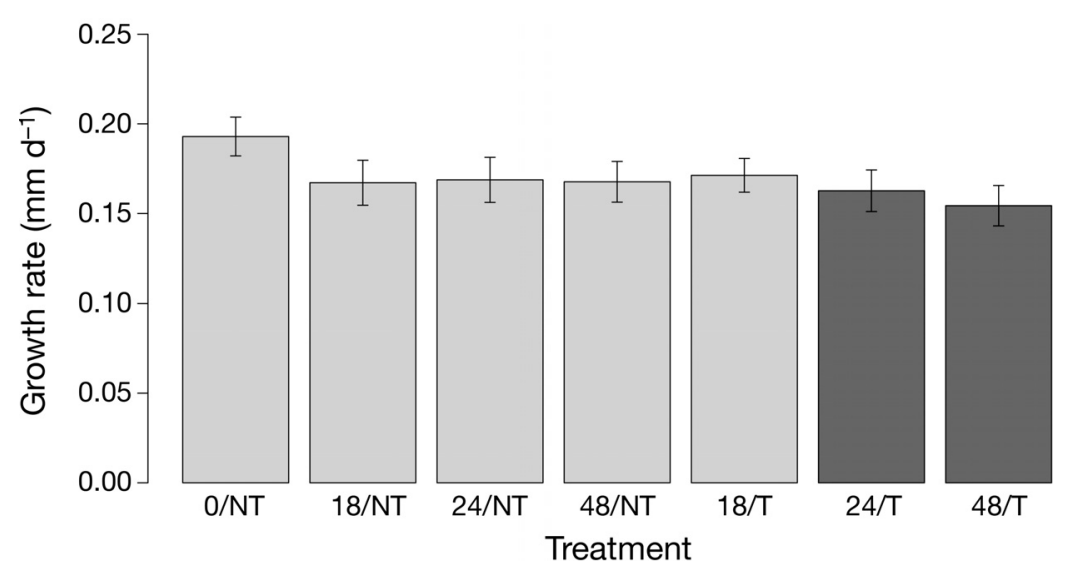

Fig. 3. Oyster growth rate for both ploidies from each of the 6 stress treatments and the control. Dark grey bars indicate growth rate of the stress treatment was significantly lower than the control (0/NT). Error bars indicate lower and upper $95 \%$ confidence limits. See Table 1 for treatment abbreviations

\subsection{Environmental parameters}

We did not find any significant interactions between ploidy, water temperature, and salinity in our analysis $(\mathrm{p}=$ $0.63)$, and thus the interaction terms were removed from the linear model. We did find that, as water temperature increased, oyster mortality (of both ploidies) increased (linear regression, $t=$ 3.74 , df $=326, \mathrm{p} \leq 0.01$ ). However, no significant relationship was found between salinity and mortality (linear regression, $t=0.01$, df $=326, \mathrm{p}=0.92$ ). Average water temperature and salinity across the 3 field sites from May through September can be seen in Table 3. 

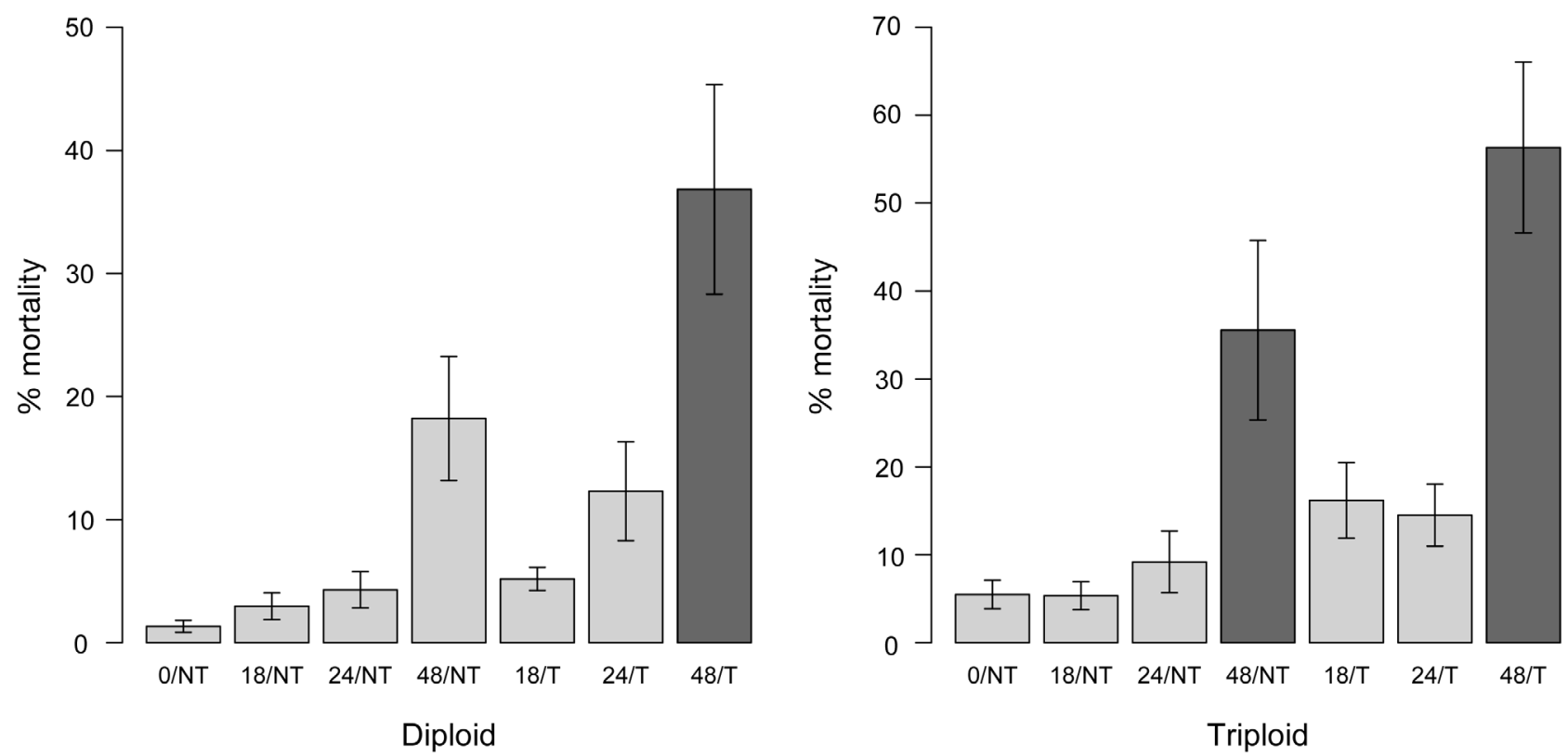

Fig. 4. Percent mortality of diploid and triploid oysters from each of the 6 stress treatments and the control (note different $y$-axis scales). Dark grey bars indicate the mortality of the stress treatment was significantly higher than the control (0/NT).

Error bars indicate lower and upper $95 \%$ confidence limits. See Table 1 for treatment abbreviations

\section{DISCUSSION}

\subsection{Growth rates}

Triploid oysters, across all stress treatments, exhibited a significant growth advantage over their diploid counterparts. The faster growth of triploid oysters may be due to both reduced gametogenesis and/or higher heterozygosity of triploid oysters, leading to lower metabolic energy costs (Hawkins \& Day 1996). Stress treatments also affected oyster growth rate; however, they did not interact with ploidy. Oysters

Table 3. Mean \pm SD water temperature, and salinity across the 3 grow-out sites in the months of May through September. Water temperature data was collected from HOBO sensors, all other data were collected from USGS. The Deer Island water temperature for August and September was also taken from the USGS as the temperature sensors may have malfunctioned. Different letters indicate significant differences $(p<0.05)$ in temperature or salinity between each month

\begin{tabular}{|lcc|}
\hline Experimental sites & Temperature $\left({ }^{\circ} \mathrm{C}\right)$ & Salinity $(\mathrm{ppt})$ \\
\hline May & $28.96 \pm 0.29^{\mathrm{a}}$ & $12.46 \pm 0.80^{\mathrm{a}}$ \\
June & $29.92 \pm 0.21^{\mathrm{b}}$ & $15.28 \pm 0.84^{\mathrm{b}}$ \\
July & $30.20 \pm 0.20^{\mathrm{b}}$ & $19.19 \pm 0.78^{\mathrm{c}}$ \\
August & $29.99 \pm 0.21^{\mathrm{b}}$ & $20.88 \pm 0.78^{\mathrm{d}}$ \\
September & $28.51 \pm 0.32^{\mathrm{c}}$ & $15.61 \pm 1.94^{\mathrm{b}}$ \\
\hline
\end{tabular}

(both diploid and triploid) subjected to any stress treatment tended to exhibit reduced growth relative to the control treatment, though only oysters in treatments 24/T and 48/T had significantly decreased growth when compared to the control (Fig. 3). Treatments 24/T and 48/T were 2 of the most severe stress treatments because they involved both extended periods of desiccation and tumbling combined. Prior studies have noted that compounding stressors, such as environmental stress and multiple induced farm stressors, can cause increased adverse effects to oysters (Cheney et al. 2000). Furthermore, intertidal oysters living in high-stress environments with more wave action have been shown to exhibit reduced growth when compared to oysters (of the same ploidy) living in lower stress environments (Ortega 1981). However, we note that in the present study, both stress treatments likely result in shell breakage as the oysters are handled during desiccation and tumbling and the observed responses may not have been explicitly slowed growth but rather greater loss of shell.

\subsection{Mortality}

In the present study, we found that triploid oysters experienced higher mortality rates than diploid oysters. Results of previous studies comparing mortality between diploids and triploids vary, with some find- 
ing mortality in triploid oysters to be much higher than in diploid oysters (Crassostrea gigas, Cheney et al. 2000; C. virginica, Wadsworth et al. 2019), some researchers finding mortality in triploids to be lower than in diploids (C. gigas, Gagnaire et al. 2006), and some finding no difference between ploidies $(C$. gigas, Dégremont et al. 2010).

Stress treatments affected the mortality of triploid oysters differently to that of diploid oysters. Regardless of tumbling, the $48 \mathrm{~h}$ desiccation treatment led to significantly higher mortality in triploids (relative to the control), while only diploids in the most severe treatment ( $48 \mathrm{~h}$ desiccation and tumbled) experienced elevated mortality (Fig. 4). Diploid and triploid oysters subjected to less severe farm stress (less than $48 \mathrm{~h}$ desiccation) tended to exhibit increased levels of mortality as compared to control oysters, though these differences were not significant and did not appear to vary between ploidies.

Furthermore, though differences were not statistically significant, mortality of triploid and diploid oysters in treatments with desiccation and tumbling were always higher than in treatments with matching desiccation times (Fig. 4). Additive farm stressors (such as tumbling and desiccation as opposed to desiccation alone) have been shown to increase oyster mortality (Ring 2012). Combinations of different stressors such as elevated water temperature, pathogens, low DO, salinity, aquaculture practices, and physiological stress associated with reproduction have long been thought to be the cause of summer mortality events (Cheney et al. 2000, Gagnaire et al. 2006, Soletchnik et al. 2007, Dégremont et al. 2012, Pernet et al. 2012). In our case, compounding stressor treatments (desiccation and tumbling) seemed to be more lethal than desiccation alone for both ploidies.

Environmental factors may have also played a role in driving oyster mortality, though both ploidies were affected similarly. As water temperatures increased, so did the mortality of both ploidies. Higher water temperatures have been correlated with increased oyster mortality before, though higher water temperature alone may not be lethal (Cheney et al. 2000). No relationship between mortality and salinity was observed in this study.

\section{CONCLUSION}

Across ploidies, the 2 most severe stress treatments (24/T and 48/T) significantly decreased growth rate. The act of putting oysters into a mechanical grader, tumbling, could have caused this reduction in growth rate due to increased shell breakage (Ring 2012). In turn, this shell breakage may have outweighed any physiological effects the stress treatments had on growth rate. However, physiological stress from high levels of desiccation and tumbling likely did play a role in reducing growth rate. All 3 tumbling treatments $(18 / \mathrm{T}, 24 / \mathrm{T}$, and $48 / \mathrm{T})$ experienced the same intensity of tumbling stress (i.e. shell breakage), only desiccation times differed among the treatments. The treatments with higher levels of desiccation (24 and $48 \mathrm{~h}$ ) displayed significantly reduced growth, indicating that a combination of tumbling and longer desiccation times led to slower growth.

The combination of tumbling and desiccation stress affected the mortality of each ploidy differently. The 2 stress treatments with the longest desiccation times (48/NT and 48/T) significantly amplified triploid oyster mortality, while diploid mortality was only significantly affected by the combination of $48 \mathrm{~h}$ desiccation and tumbling. However, this interactive effect was not significant at lower levels of stress treatments. Overall, triploid oysters experienced higher mortality than diploid oysters $(\sim 7 \%)$, and the mortality of both ploidies tended to increase compared to the control (though not always significantly) when oysters were subjected to any stress treatment. Additionally, the mortality of both ploidies increased as the water temperature increased. Many farmers already treat oysters with more care during the summer, reducing handling stress and desiccation time. It is impractical, however, for farmers to completely avoid imposing stress on oysters during the summer, as desiccation and tumbling are necessary practices in order to produce the highest grade of oyster (Ring 2012). Based on the present study, we recommend that farmers limit the desiccation time of oysters, particularly of triploid oysters, during the summer. In this study, mortality generally increased with desiccation time, with triploids and tumbled diploids exhibiting significantly higher mortality when desiccated for $48 \mathrm{~h}$.

Another solution could be selectively breeding oysters that are more resistant to heat and environmental stress. Stock selection for the purpose of lowering oyster mortality due to stressors has been successfully performed. Casas et al. (2017) produced a line of oysters that were more resistant to dermo disease, caused by Perkinsus marinus, and exhibited lower mortality than unselected oyster stock. Additionally Dégremont et al. (2010) compared diploid oysters whose parents had been selected for resistance to summer mortality to triploid oysters with a diploid parent selected for resistance. A positive response to 
survival was found for both these diploid and triploid lines, demonstrating the potential for selective breeding. However, the diploids still had higher survival than the triploids, possibly because the selected diploid parents only contributed a third of the chromosomes to the triploid offspring. Selecting for resistance in tetraploid, as well as diploid, parents would create a triploid line with higher resistance to summer mortality events (Callam 2013).

Acknowledgements. Thank you to James Stoeckel, Ruth H. Carmichael, F. Scott Rikard, Glen Chaplin, Brian Callam, Jason Rider, Grant R. Lockridge, Timothy P. McDonald, and Pengmin Pan for providing guidance and assistance with this research. Thank you also to the staff at the AUSL, the Michael Voisin Oyster Research Lab and Hatchery, and the Mississippi Department of Marine Resources for all of their help with field work and lab work. This research was supported by an award from the Gulf States Marine Fisheries Commission and by Auburn University.

\section{LITERATURE CITED}

Bates D, Mächler M, Bolker B, Walker S (2015) Fitting linear mixed-effects models using lme4. J Stat Softw 67:1-48

Callam BR (2013) Improvements in triploid Crassostrea virginica production: characterizing the diploid parent. MSc dissertation, College of William and Mary, Williamsburg, VA

Callam BR, Allen SK Jr, Frank-Lawale A (2016) Genetic and environmental influence on triploid Crassostrea virginica grown in Chesapeake Bay: growth. Aquaculture 452:97-106

Casas S, Walton W, Chaplin G, Rikard S, Supan J, La Peyre $\mathrm{J}$ (2017) Performance of oysters selected for dermo resistance compared to wild oysters in northern Gulf of Mexico estuaries. Aquacult Environ Interact 9:169-180

Cheney DP, Macdonald BF, Elston RA (2000) Summer mortality of Pacific oysters, Crassostrea gigas (Thunberg): initial findings on multiple environmental stressors in Puget Sound, Washington 1998. J Shellfish Res 19:353-359

Dégremont L, Soletchnik P, Boudry P (2010) Summer mortality of selected juvenile Pacific oyster Crassostrea gigas under laboratory conditions and in comparison with field performance. J Shellfish Res 29:847-848

Dégremont L, Garcia C, Frank-Lawale A, Allen SK Jr (2012) Triploid oysters in the Chesapeake Bay: comparison of diploid and triploid Crassostrea virginica. J Shellfish Res 31:21-31

Gagnaire B, Soletchnik P, Madec P, Geairon P, Le Moine O, Renaulta R (2006) Diploid and triploid Pacific oysters, Crassostrea gigas (Thunberg), reared at two heights above sediment in Marennes-Oleron Basin, France: Difference in mortality, sexual maturation and haemocyte parameters. Aquaculture 254:606-616

Editorial responsibility: Brett Dumbauld,

Newport, Oregon, USA
Grice R, Walton W (2017) Alabama shellfish aquaculture situation and outlook report: production year 2016. Auburn University Marine Extension and Research Center, AL

* Grodeska SM, Jones JL, Arias CR, Walton WC (2017) Effects of desiccation practices of cultured Atlantic oysters (Crassostrea virginica) on Vibrio spp. in Portersville Bay, Alabama, USA. J Food Prot 80:1280-1287

*Hawkins AJS, Day AJ (1996) The metabolic basis of genetic differences in growth efficiency among marine animals. J Exp Mar Biol Ecol 203:93-115

Housin M, Trancart S, Denechere L, Oden E, Adeline B, Lepoitevin M, Pitel PH (2019) Abnormal mortality of triploid adult Pacific oysters: Is there a correlation with high gametogenesis in Normandy, France? Aquaculture 505:63-71

Hudson K, Murray TJ (2015) Virginia Shellfish Aquaculture Situation and Outlook Report: Results of the 2014 Virginia Shellfish Aquaculture Crop Reporting Survey. VIMS Marine Resource Report No. 2015-3. Virginia Sea Grant-15-01. Virginia Institute of Marine Science, College of William and Mary, Williamsburg, VA

* Ibarra AM, Ascencio-Michel R, Ramírez JL, Manzano-Sarabia M, Rodríguez-Jaramillo C (2017) Performance of diploid and triploid Crassostrea gigas (Thunberg, 1793) grown in tropical versus temperate natural environmental Conditions. J Shellfish Res 36:119-139

NOAA Fisheries (2016) Fisheries of the United States, 2016. www.fisheries.noaa.gov/feature-story/fisheries-unitedstates-2016 (accessed on 28 March 2019)

* Ortega S (1981) Environmental stress, competition and dominance of Crassostrea virginica near Beaufort, North Carolina, USA. Mar Biol 62:47-56

* Pernet F, Barret J, Le Gall P, Corporeau C and others (2012) Mass mortalities of Pacific oysters Crassostrea gigas reflect infectious diseases and vary with farming practices in the Mediterranean Thau lagoon, France. Aquacult Environ Interact 2:215-237

R Core Team (2018). R: a language and environment for statistical computing. R Foundation for Statistical Computing, Vienna

Ring CC (2012) Evaluation of a mechanical grader for the improvement of the aquaculture production of the Eastern oyster, Crassostrea virginica, in the northern Gulf of Mexico. MSc dissertation, Auburn University, AL

* Soletchnik P, Ropert M, Mazurié J, Gildas Fleury P, Le Coz F (2007) Relationships between oyster mortality patterns and environmental data from monitoring databases along the coasts of France. Aquaculture 271:384-400

United States Geological Survey (2018) National water information system. https://waterdata.usgs.gov/usa/nwis/ uv?07380251 (accessed on 13 September 2018)

Wadsworth P (2017) Comparing triploid and diploid growth and mortality in farmed oysters, Crassostrea virginica, in the Northern Gulf of Mexico. MSc dissertation, Auburn University, AL

WWadsworth P, Casas S, La Peyre J, Walton W (2019) Elevated mortalities of triploid eastern oysters cultured offbottom in northern Gulf of Mexico. Aquaculture 505: 363-373

Submitted: May 2, 2019; Accepted: November 23, 2020 Proofs received from author(s): February 5, 2021 